\title{
OPTIMALISASI PEMBIAYAAN MUDARABAH WIRAUSAHA BERBASIS HUMANISME
}

\author{
Muhammad Surono Rauf \\ Program Pascasarjana UIN Alauddin Makassar \\ muhammad.surono@gmail.com
}

\begin{abstract}
Abstrak: Tujuan dalam penelitian ini untuk pembiayaan mudharabah BNI Syariah Makassar dan pembiayaan mudharabah berbasis humanisme. Jenis penelitian yang digunakan adalah bersifat deskriptif yakni mendeskripsikan dan menganalisa temuan yang didapat. Penelitian deskriptif bermaksud untuk mengumpulkan informasi mengenai status suatu variabel atau tema, gejala atau keadaan yang ada. Dengan demikian, peneliti akan memaparkan data atau menganalisis data-data yang diperoleh berkaitan dengan optimalisasi pembiayaan mudharabah di BNI Syariah Makassar. Hasil penelitian dalam beberapa point antara lain bahwa optimalisasi sistem pembiayaan mudharabah pada BNI Syariah dalam hal ini ada beberapa upaya yang dilakukan, Pertama; Penyaluran Pembiayaan mudharabah dengan basis humanisme, Kedua; Memberikan pembiayaan mudharabah kepada nasabah dengan cara khusus dam kepada nasabah inti. Ketiga; Memaksimalkan kuantitas dan meningkatkan kualitas SDI (Sumber Daya Insani) Bank Syariah. Humanisme yang dimiliki BNI Syariah mempunyai kelebihan yaitu dari sisi humanisme dalam pembiayaan mudarabah, karakter merupakan ciri khusus yang berbeda dengan bank syariah lainnya, sehingga dalam proses pembiayaan memberikan kenyamanan dari unsur pegawainya kepada setiap nasabah pembiayaan mudarabah.
\end{abstract}

Kata Kunci: Pembiayaan; Mudharabah; Basis Humanisme; Perbankan Islam

\section{PENDAHULUAN}

Perekonomian yang berdasarkan nilai dan prinsip syariah sudah cukup lama dinantikan oleh umat Islam di Indonesia maupun dari belahan dunia lainnya. Penerapan nilai-nilai prinsip syariah dalam segala aspek kehidupan dalam aktivitas transaksi antar umat didasarkan pada aturan-aturan syariah sudah cukup lama diperjuangkan diharapkan eksis dalam pembangunan ekonomi. Keinginan ini didasari oleh suatu kesadaran untuk menerapkan Islam secara utuh dan total dalam segala aspek kehidupan. Selama Islam diterapkan secara parsial, maka umat Islam mengalami keterpurukan duniawi dan kerugian ukhrawi. Hal ini sangat jelas, sebab selama Islam hanya diwujudkan dalam bentuk ritualisme ibadah semata, hanya diingat pada saat kelahiran bayi, ijab qabul pernikahan, serta penguburan mayat, sementara dimarginalkan dari dunia politik, ekonomi, perbankan, asuransi, pasar modal, pembiayaan proyek, dan transaksi eksporimpor, maka umat Islam telah mengubur Islam dalam-dalam dengan tangannya sendiri. 
Begitu pentingnya perbankan, sehingga ada anggapan bahwa bank merupakan poros untuk menggerakkan roda perekonomian suatu negara, sebagaimana dikemukakan oleh Kasmir bahwa "Bank sebagai lembaga keuangan yang kegiatan usahanya adalah menghimpun dana dari masyarakat dan menyalurkan kembali dana tersebut ke masyarakat serta memberikan jasa-jasa bank lainnya". Bank di Indonesia terbagi dalam dua kelompok yaitu bank berdasarkan prinsip konvensional. Bank berdasarkan prinsip syariah, yaitu bank berdasarkan prinsip syariah yang belum lama berkembang di Indonesia.

Bank merupakan lembaga keuangan yang mempunyai peranan yang strategis dalam menyerasikan dan mengembangkan unsur-unsur trilogi pembangunan nasional. Kegiatan utama dari perbankan adalah menyerap dana dari masyarakat. Keberadaan lembaga perbankan selain berpengaruh terhadap dunia usaha, hampir semua dunia usaha mengandalkan jasa finansial perbankan, juga telah banyak menyerap jutaan orang tenaga kerja. Fungsi utama bank merupakan fungsi (tumpuan) yang sangat penting bagi masyarakat dan dunia usaha adalah sebagai tempat penyimpanan dana, dan memberikan pembiayaan kepada masyarakat.

"Bank syariah atau bank Islam adalah badan usaha yang fungsinya sebagai penghimpun dana dari masyarakat dan penyalur dana kepada masyarakat, yang sistem dan mekanisme kegiatan usahanya berdasarkan hukum Islam sebagaimana yang diatur dalam al-Qur'an dan hadis" ${ }^{20}$. Bank syariah memiliki produk atau jasa yang tidak ditemukan dalam operasi bank konvesional. Prinsip-prinsip seperti musyarakah, mudarabah, murabahah, ijarah, istishna, dan sebagainya tidak memuat adanya prinsip bunga seperti yang dikembangkan oleh bank konvesional. Oleh karena itu Bank Syariah mengalami perkembangan yang semakin pesat, Hal ini dapat dilihat dari banyaknya dibuka cabang-cabang Bank Syariah yang ada di Indonesia khususnya di Kota Makassar.

Setiap perusahaan memiliki tujuan yang sama yaitu memperoleh laba (profit). Tujuan utama perusahaan adalah memaksimalkan laba. Laba merupakan indikator prestasi atau kinerja perusahaan yang besarnya tampak di laporan keuangan.

Untuk menghasilkan keuntungan, perusahaan harus melakukan kegiatan operasionalnya. Keuntungan yang dimaksudkan dalam penelitian ini adalah laba operasional. Angka laba operasional adalah selisih laba kotor dengan biaya-biaya operasi. Biaya-biaya operasi adalah biaya-biaya yang berhubungan dengan operasi perusahaan.

Dalam kegiatan Bank Syariah, mudarabah merupakan salah satu bentuk akad pembiayaan yang diberikan kepada nasabah. Sistem mudarabah ini

\footnotetext{
${ }^{1}$ Kasmir, Manajemen Perbankan, Ed.revisi (Cet.VIII: Jakarta : Rajawali Pers, 2008), h.11.

${ }^{2}$ Rachmadi Usman, Aspek-Aspek Hukum Perbankan di Indonesia (Jakarta: Gramedia Pustaka, Utama, 2005), h. 73.
} 
merupakan akad kerja sama usaha antara dua pihak dimana pihak pertama menyedi seluruh modal, sedangkan pihak lainnya menjadi pengelola. Keuntungan usaha dibagi menurut kesepakatan yang dituangkan dalam kontrak. Dalam penentuan kontraknya, harus dilakukan diawal ketika memulai akad mudarabah. Prinsip bagi hasil merupakan karakteristik umum dan landasan dasar bagi operasional bank syariah scara keseluruhan. Secara syariah prinsip berdasarkan pada kaidah mudarabah berfungsi sebagai mitra baik penabung maupun pengusaha yang meminjam dana.

Hasil ini memfokuskan penelitian pada Optimalisasi Pembiayaan Mudarabah Wirausaha Berbasis Humanisme, Wirausaha adalah pembiayaan modal kerja dan atau investasi yang diberikan untuk usaha produktif yang feasible dan bankable sesuai dengan prinsip syariah.

Hasil ini lebih kepada basis humanisme, humanisme lebih pada Individu pegawai pada pendekatannya. Dalam pelaksanaan proses pembiayaan sangat besar peranannya pegawai dalam melakukan proses pembiayaan mudarabah. Maka dari itu dilakukan penelitian terhadap pegawai sebagai sumber pelaksana pembiayaan di dalam sebuah perusahaan. Sisi humanisnya dibahas berkenaan dengan pembiayaan mudarabah. Hasil dari sebuah proses yang dipengaruhi langsung oleh pegawai sebagai pelaksana proses dan kebij produk dalam perusahaan.

Namun fenomena yang terjadi selama ini bahwa pembiayaan mudarabah wirausaha oleh Bank Syariah masih sangat membutuhkan pendekatan dari pegawainya dengan basis humanisnya, agar dapat mempengaruhi sebuah pembiayaan dan menjadikan sebuah hasil yang maksimal dan sesuai dengan prinsip syariah.

Adanya pembiayaan mudarabah pada Bank Syariah yang lebih kecil dibanding pembiayaan murabahah, maka perlu dilakukan penelitian mengenai pembiayaan mudarabah wirausaha khususnya optimalisasi produk tersebut dengan pendekatan berbasis humanisme.

\section{TINJAUAN TEORETIS}

\section{A. Pengertian Pembiayaan Mudharabah Wirausaha}

Pembiayaan secara luas berarti "financing atau pembelanjaan yaitu pendanaan yang dikeluarkan untuk mendukung investasi yang telah direncanakan, baik dilakukan sendiri atupun dikerjakan oleh orang lain". Dalam arti, pembiayaan dipakai untuk mendefenisikan pendanaan yang dilakukan oleh lembaga pembiayaan, seperti bank syariah kepada nasabah. ${ }^{3}$

${ }^{3}$ Muhammad, Manajemen Bank Syariah,(Cet.I:Yogyakarta: UPP AMP YKPN, 2005), h.260. 
Pengertian pembiayaan secara umum adalah penyediaan uang atau tagihan yang dapat dipersam dengan itu, berdasarkan persetujuan atau kesepakatan antara bank dengan ihak lain yang mewajibkan pihak yang dibiayai untuk mengembalikan uang atau tagihan tersebut setelah jangka waktu tertentu dengan imbalan atau bagi hasil. ${ }^{4}$

Pembiayaan berprinsip syariah ${ }^{5}$ adalah penyediaan dana berdasarkan kesepakatan pinjam meminjam antara bank dengan pihak lain, dengan ketentuan pihak peminjam wajib melunasi hutangnya setelah jangka waktu tertentu dengan menyert bagi hasilnya. Sedangkan Kasmir juga menjelaskan pembiayaan adalah penyediaan uang atau tagihan yang dapat dipersam dengan itu, berdasrkan persetujuan atau kesepakatan antara bank dengan pihak lain yang mewajibkan pihak yang dibiayai untuk mengembalikan uang atau tagihan tersebut setelah jangka waktu tertentu dengan imbalan atau bagi hasil. Dengan demikian pengertian pembiayaan adalah penyediaan dana oleh bank yang disalurkan kepada pihak lain dengan ketentuan pengembalian dengan menyert imbalan atau bagi hasil.

Dalam pembiayaan terdapat kontrak yang harus dilakukan oleh dua pihak yaitu shahibul mal dan mudharib. Kontrak pembiayaan adalah pengikatan dua pihak dengan kesepakatan-kesepakatan, diantaranya adalah kesepakatan tentang lama atau waktu kontrak. unsur yang terkandung dalam pembiayaan yaitu ${ }^{6}$ :

1) Kepercayaan

Yaitu keyakinan pihak pemberi dana bahwa dana yang diberikan benarbenar dikembalikan dimasa yang datang.

2) Kesepakatan

Kesepakatan diwujudkan dalam bentuk perjanjian dimana masing-masing pihak menandatangani hak dan kewajiban masing-masing.

3) Jangka waktu

Jangka waktu mencakup masa panjang atau pendeknya pemberian dana harus dikembalikan.

4) Resiko

Resiko kerugian dapat diakibatkan dua yaitu kesengajaan nasabah yang tidak mau mengembalikan dana, padahal nasabah mampu untuk mengembalikan, dan karena pembiayaan. Masyarakat yang berpotensi mengembangkan usahannya dapat bekerja sama dengan bank syari'ah untuk mencukupi kebutuhan modal usahannya.

Secara etimologi (bahasa) "al mudarabah" berasal dari kata adhdhard yang memiliki dua relevansi antara keduanya, yaitu: pertama karena melakukan usaha (amil) dan yadhribfilardhi (berjalan di muka bumu) dengan bepergian padanya

\footnotetext{
${ }^{4}$ Kasmir, Bank dan Lembaga Keuangan Lainnya,(Jakarta: PT Raja Grafindo Persada, 2007), h 96.

${ }_{5}$ Ridwan, Perbankan Syariah, (Jakarta: PT.Grafika, 2007), h.92.

${ }^{6}$ Kasmir, Pembiayaan Bank, (Jakarta: PT.Gema Insani, 2004), h.75.
} 
untuk bedagang, maka berarti ia berhak mendapat keuntungan karena usaha dan kerjanya ${ }^{7}$. Seperti firman Allah Q.S.:

"dan sebagian orang-orang yang lain berjalan di muka bumi mencari sebagian karunia Allah, kedua karena masing-masing orang yang bersyarikat yadhribu bisahmin (memotong atau mengambil bagian) dalam keuntungan.

Defenisi yang representif bagi mudarabah sebagai jalan tengah antara mazhab Syafi'i dan Mazhab Hambali yaitu suatu akad atau kontrak yang memuat penyerahan modal khusus atau semaknanya tertentu dalam jumlah, jenis dan karakternya (sifatnya) dari ornag yang diperbolehkan mengelola harta (Jaizattashruf) kepada orang lain yang aqil, mumayyiz, dan bijaksana, yang ia pergun untuk berdagang dengan mendapatkan bagian tertentu dari keuntungannya menurut nisbah pembagiannya dalam kesepakatan ${ }^{8}$.

Aplikasi prinsip mudarabah dibagi menjadi dua yaitu mudarabah muthlaqah dan mudarabah muqayyadah. Mudarabah Muthlaqah adalah bentuk kerjasama antara shahibulmaal dan mudharib yang tidak dibatasi oleh spesifikasi jenis usaha, waktu dan daerah bisnis. Sedangkan mudarabah muqayyadah adalah kerjasama yang mana mudahrib dibatasi jenis usaha, waktu dan tempat usaha.

Secara istilah, mudarabah adalah akad kerjasama antara shahibul maal (pemilik modal) dengan mudharib (yang mempunyai keahlian dan keterampilan) untuk mengelolah suatu usaha yang produktif atau halal. Hasil dari penggunaan dana tersebut dibagi bersama berdasarkan nisbah yang disepakati, jika terjadi kerugian di tanggug shahibul maal. Prinsip bagi hasil dalam mudarabah mendasarkan pengelolaan usahanya dengan filosofi utama kemitraan.

Mudarabah dalam perspektif fikih merupakanakan kontak yang melibatkan antara dua kelompok, yaitu pemilik modal (investor) yang mempercayakanakan modalnya kepada pengelola (mudharib) untuk digunakan dalam aktifitas perdagangan. Sedangkan keuntungan dagang itu dibagi menurut kesepakatan bersama. Mudharib dalam hal ini memberi konstribusi pekerjaan, waktu dan mengelola usahanya sesuai dengan ketentuan yang dicapai dalam kontrak, salah satunya untuk mencapai keuntungan (profit) yang dibagi antara pihak investor dan mudharib berdasarkan proporsi yang disetujui bersama. Namun apabila terjadi kerugan yang menanggung adalah pihak ivestor saja.

Menurut istilah, mudarabah atau qirad dikemukakan oleh para ulama sebagai berikut: ${ }^{9}$

1. Menurut para fuqaha, mudarabah ialah akad antara dua pihak (orang) saling menanggung, salah satu pihak menyerahkan hartanya kepada pihak lain untuk diperdagangkan dengan bagian yang telah ditentukan dari keuntungan, seperti setengah atau sepertiga dengan syarat-syarat yang telah ditentukan.

2. Ulama Syafiiyah berpendapat bahwa mudarabah ialah akad yang

\footnotetext{
${ }^{7}$ Bambang Rianto Rustam, Bank Syariah, ( Jakarta: PT.Raja Grafindo, 2012), h. 109.

${ }^{8}$ Rahmat Syafi'i, Fiqih Muamalah, ( Pustaka setia: Bandung, 2001), h.35.

${ }^{9}$ Ahmad Wardi Muslich, Fiqih Muamalat, Ed.I, (Cet.I: Jakarta: Amzah, 2010), h.370.
} 
menentukan seseorang menyerahkan hartanya kepada yang lain untuk ditijarahkan.

3. Sayyid Sabiq berpendapat bahwa, mudarabah ialah akad antara dua belah pihak untuk salah satu pihak mengeluarkan sejumlah uang untuk diperdagangkan dengan syarat keuntungan dibagi dua sesuai dengan perjanjian.

Mudarabah merupakan kontrak yang melibatkan antara dua kelompok, yaitu pemilik modal (investor) yang mempercayakan modalnya kepada pengelola (mudharib) untuk digunakan dalam aktivitas perdagangan. Mudharib dalam hal ini memberikan kontribusi pekerjaan, waktu, dan mengelola usahanya sesuai dengan ketentuan yang dicapai dalam kontrak, salah satunya adalah untuk mencapai keuntungan (profit) yang dibagi antara pihak investor dan mudharib berdasarkan proporsi yang telah disetujui bersama.

Wirausaha berarti seorang yang berani berusaha secara mandiri dengan mengerahkan segala sumber daya dan upaya meliputi kepandaian mengenali produk baru, menentukan cara produksi baru, menyusun operasi untuk pengadaan produk baru, memasarkannya, serta mengatakanur permodalan operasinya untuk menghasilkan sesuatu yang bernilai lebih tinggi.

Fasiltas pembiayaan produktif yang ditujukan untuk memenuhi kebutuhan pembiayaan usaha-usaha produktif (modal kerja dan investasi) yang tidak bertentangan dengan syariah dan ketentuan peraturan perundangan yang berlaku.

Keunggulan produk pembiayaan wirausaha :

a) Proses lebih cepat dengan persyaratan mudah sesuai dengan prinsip Syariah.

b) Jangka waktu pembiayaan sampai dengan 7 (tujuh) tahun.

c) Plafond pembiayaan minimal Rp. 50 Juta dan maksimum Rp.1 (satu) Milyar.

d) Pembayaran angsuran dapat dilakukan di seluruh Kantor Bank BNI Syariah maupun BNI Konvensional.

Syarat Permohonan Pembiayaan ${ }^{10}$ :

a) Warga Negara Indonesia.

b) Pengalaman dibidang usaha minimal 2 (dua) tahun.

c) Identitas diri (Kartu Keluarga (KK) dan KTP).

d) Legalitas usaha lengkap dan masih berlaku (SIUP, TDP, HO dan SITU).

e) Surat keterangan berusaha dari kelurahan/kecamatan khusus untuk pembiayaan sampai dengan Rp.150 Juta.

f) Bukti kepemilikan agunan yang sah dan masih berlaku.

10 Dwiono Koesin, Pembiayaan Wirausaha iB Hasanah, , july 2014, h.21. http://www,bnisyariah.co.id/produk/bnis-wirausaha, diakses Tanggal 30 april 2018. 
g) NPWP (perorangan/perusahaan).

h) Tidak termasuk dalam daftar hitam Bank Indonesia serta tidak tercatat sebagai nasabah pembiayaan macet/bermasalah.

i) Menyampaikan fotocopy rekening bank selama 6 (enam) bulan terakhir (bila ada).

Menurut Kamus Besar Bahasa Indonesia, pengertian wirausaha sama dengan wiraswasta, yaitu orang yang pandai atau berbakat mengenali produk baru, menentukan cara produksi baru, menyusun operasi untuk pengadaan produk baru, memasarkannya, serta mengatakanur permodalan operasinya.

Wirausaha pelaku utama dalam pembangunan ekonomi dan fungsinya untuk melakukan inovasi atau kombinasi-kombinasi yang baru untuk sebuah inovasi.

Dengan melakukan sebuah proses yang disebut creative destruction(pengrus yang kreatif) untuk menghasilkan suatu nilai tambah (added value) guna menghasilkan nilai yang lebih tinggi, sehingga inti dari keterampilan wirausaha adalah kreativitas. Wirausaha adalah orang yang berani mengusah suatu pekerjaan baik untuk diri sendiri ataupun untuk orang lain.

Wirausaha bisa menjadikan pengusaha yang telah mampu mengelola sumber-sumber daya yang dimiliki secara ekonomis (efektif dan efisien) dan tingkat produktivitas yang rendah menjadi tinggi.

Orang yang mampu mengelola, mengorganisasikan, dan berani menanggung segala resiko untuk mencipt peluang usaha dan usaha baru ${ }^{11}$.

Seseeorang yang telah berani berusaha secara mandiri dengan mengerahkan segala sumber daya dan upaya meliputi kepandaian mengenali produk baru, menentukan cara produksi baru, menyusun operasi untuk pengadaan produk baru, memasarkannya, serta mengatakanur permodalan operasinya untuk menghasilkan sesuatu yang bernilai lebih tinggi. wirausaha adalah seorang yang berani berusaha secara mandiri dengan mengerahkan segala sumber daya dan upaya meliputi kepandaian mengenali produk baru, menentukan cara produksi baru, menyusun operasi untuk pengadaan produk baru, memasarkannya, serta mengatakanur permodalan operasinya untuk menghasilkan sesuatu yang bernilai lebih tinggi.

Pengertian wirausaha sama dengan wiraswasta, yaitu orang yang pandai atau berbakat mengenali produk baru, menentukan cara produksi baru, menyusun operasi untuk pengadaan produk baru, memasarkannya, serta mengatakanur permodalan operasinya. ${ }^{12}$

\footnotetext{
${ }^{11}$ Dan Stein dan Jhon F.Burgess, Bank, (Jakarta: PT Raja Grafindo, 1993), h 10.

12 Poerwadaminta, Kamus Umum Indonesia, (Cet.VII:Jakarta: Balai Pustaka, 1991), h.
} 269. 
Wirausaha pelaku yang utama dalam pembangunan ekonomi dan fungsinya untuk melakukan inovasi atau kombinasi-kombinasi yang baru untuk sebuah inovasi.

Orang yang melakukan sebuah proses yang disebut creative destruction (pengrus yang kreatif) untuk menghasilkan suatu nilai tambah (added value) guna menghasilkan nilai yang lebih tinggi, sehingga inti dari keterampilan wirausaha adalah kreativitas. Wirausaha merupakan orang yang berani mengusah suatu pekerjaan baik untuk diri sendiri ataupun untuk orang lain.

Entrepreneurial is an innovator and individual developing something unique and new (wirausaha adalah seorang penemu dan individu yang membangun sesuatu yang unik dan baru). ${ }^{13}$

Pengusaha yang telah mampu mengelola sumber-sumber daya yang dimiliki secara ekonomis (efektif dan efisien) dan tingkat produktivitas yang rendah menjadi tinggi.

Wirausaha seperti orang yang mengelola, mengorganisasikan, dan berani menanggung segala resiko untuk menciptakankan peluang usaha dan usaha baru. Menurut Schumpeter wirausaha adalah seorang yang memperoleh peluang dan menciptakankan organisasi untuk mengejar peluang tersebut.

Wirausaha orang yang mampu mengubah kesempatan menjadi sebuah ide yang bisa di jual ${ }^{14}$, dapat memberikan nilai tambah melalui upaya, waktu, biaya, serta kecakapan dengan tujuan mendapatkan keuntunganwirausaha adalah seorang yang berani berusaha secara mandiri dengan mengerahkan segala sumber daya dan upaya meliputi kepandaian mengenali produk baru, menentukan cara produksi baru, menyusun operasi untuk pengadaan produk baru, memasarkannya, serta mengatakanur permodalan operasinya untuk menghasilkan sesuatu yang bernilai lebih tinggi. Wirausaha adalah seorang yang berani berusaha secara mandiri dengan mengerahkan dari segala sumber daya dan upaya meliputi kepandaian mengenali produk baru, menentukan cara produksi baru, menyusun operasi untuk pengadaan produk baru, memasarkannya, serta mengatakanur permodalan operasinya untuk menghasilkan sesuatu yang bernilai lebih tinggi.

Orang atau pelaku utama dalam pembangunan ekonomi dan fungsinya untuk untuk melakukan inovasi atau kombinasi-kombinasi yang baru untuk sebuah inovasi. Tujuan kewirausahaan sosial adalah terwujudnya perubahan sosial ke arah yang lebih baik atau positif dan memecahkan masalah sosial untuk kepentingan masyarakat. ${ }^{15}$

13 Stein dan Jhon F.Burgess, Bank Konvensional, (Jakarta: PT.Gratika, 1993), h.21.

${ }^{14}$ Mas'ud Machfoedz dan Mahmud Machfoedz, Bank Konven, (Jakarta: PT.Rajawali, 2004), h.32.

${ }^{15}$ Rintan Saragih, Membangun Usaha Kreatif inovatif melalui kewirausahaan (Jakarta: Jurnal kewirausahaan, 2017), h.12. 
Wirausaha melakukan sebuah proses yang disebut creative destruction (pengrus yang kreatif) untuk menghasilkan suatu nilai yang bertambah (added value) guna menghasilkan nilai yang lebih tinggi, sehingga inti dari keterampilan, wirausaha adalah kreativitas. Wirausaha bisa juga orang yang berani mengusah suatu pekerjaan baik untuk diri sendiri ataupun untuk orang lain.

Wirausaha bisa seseorang inovator yang mampu mengubah kesempatan menjadi sebuah ide yang bisa di jual, dapat memberikan nilai tambah melalui upaya, waktu, biaya, serta kecakapan dengan tujuan mendapatkan keuntungan.

\section{B. Dasar Hukum Mudharabah}

Ayat-ayat yang walaupun tidak langsung, tetapi maksudnya dapat digunakan sebagai dasar atau landasan kebolehan mudarabah, seperti ayat-ayat tentang perintah mencari karunia Allah swt, diantaranya adalah firman Allah dalam QS al Muzammil/73: 20 .

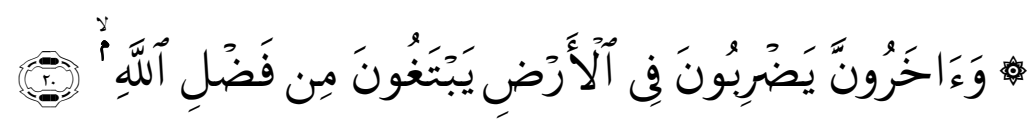

Terjemahannya:

"Dan orang-orang yang berjalan dimuka bumi mencari sebagian karunia Allah. "16

Ayat tersebut menjelaskan bahwa sebagai manusia yang hidup dimana, maka kiranya senantiasa mencari rizki (karunia Allah) dengan bermuamalah, salah satunya yaitu dengan kerjasama antara manusia. Dasar hukum mudarabah yang kedua adalah al-Sunnah. Selain al-Quran, hadits sebagai salah satu sumber hukum Islam juga memberikan landasan tentang mudarabah, atau qirad. Adapun hadits tentang mudarabah:

"Abbas bin Abdul Muthalib jika menyerahkan harta sebagai mudharabah, ia mensayaratkan kepada mudharibnya agar tidak mengarungi lautan dan tidak menuruni lembah, serta tidak membeli hewan ternak".

Dasar mudarabah yang ketiga adalah Ijma', Berdasarkan Ijma' golongan sahabat yang sesungguhnya tidak menolak harta anak yatim untuk dilakukan mudarabah yang berdasarkan pada ijtihad Umar bin Khatab ${ }^{17}$, diriwayatkan oleh Abdillah bin Zaid bin Aslam yang mengatakani bahwa Abdullah dan Ubaidillah Purta-putra Umar bin Khatab r.a. keluar bersama pasukan Irak. Ketika mereka kembali, mereka singgah pada bawahan Umar, yaitu Musa al-Asya'ri, Gubernur Bashrah ia memerima mereka dengan senang hati dan berkata, sekiranya aku dapat memberikan pekerjaan kepada kalian yang bermanfaat, aku melakukannya kemudian ia berkata: sebetulnya bagian ini adalah sebagian dari harta Allah yang

${ }^{16}$ Departemen Agama RI, Al-Qur'anul Karim dan Terjemahnya, ( Semarang: CV. Toha Putra,2014), h.110

${ }^{17}$ (Antonio, 2012: 96) 
aku ingin kirimkan kepada Amirulmu'minin. Aku pinjamkan kalian untuk dipakai membeli barang yang ada di irak. Kemudian kalian jual di Madinah. Kalian serahkan modal pokoknya kepada Amirulmu'minin, dengan demikian kalian mendapatkan keuntungan keduanya berkata; kami senang melakukannya, kemudian Abu Musa melakukannya dan menulis surat kepada Umar agar beliau mengambil harta dari keduanya. Setelah mereka tiba, mereka menjual barang tersebut dan mendapatkan keuntungan, Umar berkata: Adakah semua pasukan telah pinjamkan uang seperti kamu? Mereka menjawab tidak, kemudian Umar berkata: Dua anak Amirulmu'minin, karena mereka meminjamkan kepada keduanya, serahkanlah harta dan labanya. Abdullah diam saja, tetapi Ubaidillah menjawab: Wahai Amirulmu'minin, kalau harta itu binasa termasuk dalam ayat diatas memang tidak ada secara tegas menerangkan tentang pelaksanaan mudarabah, tetapi dari berbagai ayat tentang muamalah, dapat diambil kesimpulan bahwa untuk bekerjasama mudarabah diperbolehkan (habis) kami menjaminnya. Umar terus berkata: serahkanlah, Abdullah diam saja Dan Ubaidillah tetap mendebatkannya. Salah seorang yang hadir dimajelis Umar tersebut berkata: Wahai Amirulmu'minin, bagaimana sekiranya harta itu anda anggap qirad, Umar lantas menyetujui pendapat ini dan mengambil modal berfikut setengah dari labanya ${ }^{18}$.

Dasar mudarabah yang keempat adalah qiyas. mudarabah dapat diqiyaskan sebagi bentuk interaksi antara sesama manusia sebagai makhluk sosial. Sebagai makhluk sosial, kebutuhan kerjasama antara satu pihak dengan pihak lain guna meningkatkan taraf perekonomian dan kebutuhan hidup, atau keperluan-keperluan lain, tidak bisa diabaikan. Kenyataan menunjukkan bahwa diantara sebagian manusia memiliki modal, tetapi tidak bisa menjalankan usahausaha produktif, tetapi berkeinginan membantu orang lain yang kurang mampu dengan jalan mengalihkan sebagian modalnya kepada pihak yang memerlukan. Disisi lain, tidak jarang pula ditemui orang-orang yang memiliki keahlian dan kemampuan berusaha secara produktif, tetapi tidak memiliki atau keterangan modal usaha. Berdasarkan kenyataan itu, sangat diperlukan adanya kerjasama pemilik modal dengan orang-orang yang tidak mempunyai atau kekurangan modal. Pada bentuk kerjasama seperti ini, pihak miskin yang kekurangan modal itu sangat terbantu, dan para pemilik modalpun tidak pula dirugikan karena pemindahan modalnya kepada pihak lain tersebut ${ }^{19}$.

Humanisme atau al-insaniyah yang artinya berperikemanusiaan, hormat menghormati sesama. Pemasaran berusaha membuat kehidupan menjadi lebih baik. Jangan sampai kegiatan pemasaran malah merusak tatanan hidup di masyarakat, menjadikan kehidupan bermasyarakat terganggu, seperti hidupnya gerombolan hewan, tidak ada aturan dan yang kuat yang berkuasa. Humanistis dapat diatrikan memanusianka manusia yaitu memperlakukan manusia seperti layaknya manusia. Tidak semena-mena dan seenaknya sendiri terutama dalam bidang pelayanan harus dilakukan dengan penuh rasa hormat. Dapat disimpulkan

\footnotetext{
${ }^{18}$ Mas'ud Machfoedz dan Mahmud Machfoedz, (Jakarta, PT.Rajawai, 2004),h.34.

19 Karim, Analisis Fiqih dan Keuangan, (Jakarta: PT.Raja Grafindo Persada, 1993), h.12.
} 
bahwa strategi pemasaran syariah merupakankana cara suatu perusahaan untuk mencapai tujuan awal dengan memayungi seluruh aktivitas dalam sebuah perusahaan, meliputi seluruh proses, mencipt, menawarkan, pertukaran nilai, dari seorang produsen, atau satu perusahaan, atau perorangan, yang sesuai dengan ajaran Islam.

Manusia modern dan sekular belum dapat menyelesaikan berbagai problematikanya. Para modernis baik dari kalangan Barat maupun Islam menyimpulkan kebutuhan manusia pascamodern yaitu adalah keluar dari krisis modernisme dan kembali kepada hikmah spiritual yang terdapat dalam agama.

Dengan tujuan yang tidak jauh berbeda dengan Nasr, Jon Avery dan Hasan Askari dua tokoh yang secara prinsip saling bertentangan secara teologis ini melakukan kompromi dan mencari titik temu melalui diskusi dan dialog. Hasilnya, konsep humanis-spiritual bisa dipertemukan. ${ }^{20}$

Atas dasar ini menurut penulis humanisme spiritual penting untuk dijadikan alternatif ${ }^{21}$, karena rasio sekular belum cukup untuk dijadikan dasar mengatakanasi dinamika persoalan masyarakat global yang kehilangan makna spiritual, karena itu harus kembali potensi manusia yang spiritualis dan humanis. Dengan menempatkan manusia sebagai makhluk yang spiritualis dan humanis, maka secara filosofis manusia yang diinginkan dalam humanisme spiritual adalah manusia yang berorientasi teo-antroposentris. Sesuai dengan karakteristiknya yang humanis dan spiritualis, humanisme spiritual mengangkat eksistensi manusia ke tempat yang sebenarnya, yakni manusia yang menghargai kemanusiaannya secara fisik dan juga menghargai kemanusiaannya yang memiliki spiritualitas ketuhanan.

Humanisme dalam Islam ditegakkan dengan dasar kemanusiaan yang murni diajarkan didalam al-Qur'an. Konsepsi Islam mengajarkan pada umatnya, bahwa Allah swt yang Maha Pengasih dan Maha Penyayang tidaklah mencipt manusia dengan sia-sia. Dia telah mengaruni panca indera, akal dan fikiran serta menjadikan manusia dalam bentuk yang sebaik-baiknya, sempurna lahir dan bathin.

Humanisme di ajaran Islam tidaklah bersifat ekstrim seperti kedua pandangan di atas. Ia tidak mendew manusia dan juga tidak merendahkannya, Islam menempatkan manusia pada proporsi sebenarnya. Manusia merupakan makhluk yang menerima amanah Tuhan agar dapat menggelola alam semesta bagi kesejahteraan bersama. Dengan demikian manusia menjadi makhluk yang paling baik dan sempurna, apabila melaksan amanah tersebut. Sebaliknya ia menjadi makhluk yang hina apabila menghianati amanat itu dan berbuat kerus di 1995), h.158

20 Jon Avery dan Hasan Askari, Bank Konvensional, (Jakarta: PT. Rajawali,

${ }^{21}$. Masduki, Humanisme Sekuler VS humanise Religius (Jakarta: Jurnal Ekonomi, 2000 ), h.7. 
muka bumi. Menurut pandangan Islam, mulia atau rendahnya menusia tidak terletak pada wujudnya semata sebagai makhluk Tuhan, tetapi terletak juga bagaimana ia dapat menjadikan dirinya bermanfaat bagi sesama makhluk hidup.

\section{METODOLOGI PENELITIAN}

Penelitian deskriptif bermaksud untuk mengumpulkan informasi mengenai status suatu variabel atau tema, gejala atau keadaan yang ada. Dengan demikian, peneliti akan memaparkan data atau menganalisis data-data yang diperoleh berkaitan dengan optimalisasi pembiayaan mudharabah di BNI Syariah Makassar.

\section{HASIL DAN PEMBAHASAN}

\section{A. Optimalisasi Pembiayaan Mudarabah}

Pembiayaan produktif di BNI Syariah menggunakan beberapa akad yang sesuai dengan syariah Islam, yaitu akad mudhārabah dan musyarakah. Untuk akad mudha rabah bank sebagai penyetor modal usaha $100 \%$ kepada pengelola usaha/nasabah. Sedangkan akad musyarakah, bank hanya menyetor sebagian modal dari keseluruhan modal yang dibutuhkan nasabah dalam menjalankan usahanya karena nasabah sendiri telah memiliki modal usaha dan bank sebagai penyedia sebagian lagi modal nasabah. Ada beberapa tempat yang bisa dipilih oleh nasabah dalam melakukan pengajuan pembiayaan usaha dengan akad mudhārabah dan akad lainnya bila berdasarkan pembiayaan yang diberikan bisa ke Cabang Reguler atau Cabang Mikro. Cabang regular pengajuannya minimal 500 juta, Jika pengajuannya lebih besar maka diputuskan oleh pusat.

Definisi yang representif bagi mudarabah sebagai jalan tengah antara mazhab Syafi'i dan Mazhab Hambali yaitu suatu akad atau kontrak yang memuat penyerahan modal khusus atau semaknanya tertentu dalam jumlah, jenis dan karakternya (sifatnya) dari ornag yang diperbolehkan mengelola harta (Jaizattashruf) kepada orang lain yang aqil, mumayyiz, dan bijaksana, yang ia pergun untuk berdagang dengan mendapatkan bagian tertentu dari keuntungannya menurut nisbah pembagiannya dalam kesepakatan.

Aplikasi prinsip mudarabah dibagi menjadi dua yaitu mudarabah muthlaqah dan mudarabah muqayyadah. Mudarabah Muthlaqah adalah bentuk kerjasama antara shahibulmaal dan mudharib yang tidak dibatasi oleh spesifikasi jenis usaha, waktu dan daerah bisnis . Sedangkan mudarabah muqayyadah adalah kerjasama yang mana mudahrib dibatasi jenis usaha, waktu dan tempat usaha.

Secara istilah, mudarabah adalah akad kerjasama antara shahibul maal (pemilik modal) dengan mudharib (yang mempunyai keahlian dan keterampilan) untuk mengelolah suatu usaha yang produktif atau halal. Hasil dari penggunaan dana tersebut dibagi bersama berdasarkan nisbah yang disepakati, jika terjadi kerugian di tanggug shahibul maal. Prinsip bagi hasil dalam mudarabah 
mendasarkan pengelolaan usahanya dengan filosofi utama kemitraan.

Mudarabah dalam perspektif fikih merupakan kontak yang melibatkan antara dua kelompok, yaitu pemilik modal (investor) yang mempercayakan modalnya kepada pengelola (mudharib) untuk digunakan dalam aktifitas perdagangan. Sedangkan keuntungan dagang itu dibagi menurut kesepakatan bersama. Mudharib dalam hal ini memberi konstribusi pekerjaan, waktu dan mengelola usahanya sesuai dengan ketentuan yang dicapai dalam kontrak, salah satunya untuk mencapai keuntungan (profit) yang dibagi antara pihak investor dan mudharib berdasarkan proporsi yang disetujui bersama. Namun apabila terjadi kerugan yang menanggung adalah pihak ivestor saja.

Menurut istilah, mudarabah atau qirad dikemukakan oleh para ulama sebagai berikut ${ }^{22}$ :

1. Menurut para fuqaha, mudarabah ialah akad antara dua pihak (orang) saling menanggung, salah satu pihak menyerahkan hartanya kepada pihak lain untuk diperdagangkan dengan bagian yang telah ditentukan dari keuntungan, seperti setengah atau sepertiga dengan syarat-syarat yang telah ditentukan.

2. Ulama Syafiiyah berpendapat bahwa mudarabah ialah akad yang menentukan seseorang menyerahkan hartanya kepada yang lain untuk ditijarahkan.

3. Sayyid Sabiq berpendapat bahwa, mudarabah ialah akad antara dua belah pihak untuk salah satu pihak mengeluarkan sejumlah uang untuk diperdagangkan dengan syarat keuntungan dibagi dua sesuai dengan perjanjian.

Mudarabah merupakanakan kontrak yang melibatkan antara dua kelompok, yaitu pemilik modal (investor) yang mempercayakan modalnya kepada pengelola (mudharib) untuk digunakan dalam aktivitas perdagangan. Mudharib dalam hal ini memberikan kontribusi pekerjaan, waktu, dan mengelola usahanya sesuai dengan ketentuan yang dicapai dalam kontrak, salah satunya adalah untuk mencapai keuntungan (profit) yang dibagi antara pihak investor dan mudharib berdasarkan proporsi yang telah disetujui bersama.

Mudarabah bisa bentuk kerja sama antara dua atau lebih pihak di mana pemilik modal (shahibul maal) mempercayakan sejumlah modal kepada pengelola (mudharib) dengan suatu perjanjian keuntungan. Bentuk ini menegaskan kerja sama dengan kontribusi seratus persen modal dari shahibul maal dan keahlian dari mudharib.

Menurut PSAK no.105 mudarabah adalah akad kerja sama antara dua pihak dimana pihak pertama (pemilik modal) menyedi seluruh modal sedangkan pihak pengelola dana bertindak selaku pengelola, keuntungan diantara mereka dibagi berdasarkan kesepakatan sedangkan kerugian ditanggung oleh pengelola

${ }^{22}$ Ahmad Wardi Muslich, Fiqih Muamalat,Ed.I, (Cet.I: Jakarta: CV. Amzah, 2010), h.370. 
$\operatorname{modal}^{23}$

Mudarabah merupakan akad kerja sama antara bank syariah sebagai penyedia dana $100 \%$ (shahibul mal) dengan nasabah atau pengusaha sebagai pengelola proyek (mudharib). Keuntungan proyek dibagi kepada kedua pihak sesuai dengan proporsi (nisbah) yang disepakati dalam perjanjian.

Apabila usaha tersebut mengalami kegagalan, sehingga karena itu terjadi kerugian yang sampai mengakibatkan sebagian atau, bahkan, seluruh modal yang ditanamkan oleh shahibul mal habis, maka yang menanggung kerugian keuangan hanya shahib al-mal sendiri, sedangkan mudharib sama sekali tidak menanggung atau tidak harus mengganti kerugian atas modal yang hilang, kecuali apabila kerugian tersebut terjadi sebagai akibat kecurangan yang dilakukan oleh mudharib.

Pola transaksi mudarabah biasanya diterapkan pada produk-produk pembiayaan dan pendanaan. Pada sisi penghimpunan dana, mudarabah diterapkan pada tabungan dan deposito. Sedangkan pada sisi pembiayaan, mudarabah diterapkan untuk pembiayaan modal kerja. Dalam sisi pembiayaan, bila seorang pedagang membutuhkan modal untuk berdagang, maka dapat mengajukan permohonan untuk pembiayaan bagi hasil seperti mudarabah.

BNI Syariah Mikro merupakan divisi yang bergerak untuk pembiayaan khusus pembiayaan Mikro mulai dari pembiayaan usaha dari 5 juta sampai dengan 500 juta. Sedangkan Reguler diartikan BNI Syariah di luar dari dari BNI Syariah mikro yang menangani pembiayaan konsumtif dan pembiayaan produktif untuk nasabah.

\section{B. Humanisme dalam Pembiayaan Mudarabah}

Bank Syariah melakuk monitoring kepada mudhārib untuk menghindari timbulnya kerugian yang lebih besar akibat menurunnya hasil yang diperoleh muḍārib. Dalam hal ini muḍārib bisa saja melakukan hal-hal yang menyimpang dari batasan-batasan yang diberikan oleh bank sehingga usaha tersebut tidak berjalan sesuai yang diharapkan bank dan berdampak pada bagi hasil yang tidak sesuai dengan yang diprediksi bank sebagai şhāhibul māal bahkan bisa saja usaha tersebut rugi. Bank dari sisi humanis melakukan program monitoring dalam mengawasi nasabah sebagai muḍhārib, misalnya memeriksa laporan berkala tiap bulan mengenai hasil yang diperoleh dari usaha muḍhārib. Tetapi ketika terjadi perubahan yang signifikan dari hasil yang dilaporkan oleh muḍhārib, maka bank sebagai şhāhibul māal melakukan monitoring yang lebih ketat kepada muḍhārib. Hal ini berkaitan dengan modal yang diberikan bank untuk usaha tersebut, supaya bank dapat mengantisipasi kerugian yang lebih besar. Misalnya muḍhārib melakukan kelalaian dalam mengelola usahanya sehingga menyebabkan kerugian. Bank dalam hal ini tidak ingin modal yang

\footnotetext{
${ }^{23}$ Muhammad, Akuntansi Bank syariah, (Yogyakarta: Trust Media, 2009), h. 56.
} 
disetornya untuk usaha tersebut habis, sehingga ketika terjadi hal-hal yang tidak biasa maka bank sebagai şhāhibul māal melakukan monitoring yang lebih kepada muḍhārib.

Mudarabah didefinisikan sebagai akad kerjasama usaha antara dua pihak dimana pihak pertama (pemilik dana atau shahibul maal) menyedi seluruh dana, sedangkan pihak kedua (pengelolah dana atau mudharib) bertindak selaku pengelolah, dan keuntungan dibagi diantara mereka sesuai kesepakatan sedangkan kerugian financial hanya ditanggung oleh pemilik dana. Kerugian ditanggung pemilik dana selama kerugian itu tidak diakibatkan oleh kelalaian pengelola dana, apabilah kerugian yang terjadi diakibatkan olehpengelola dana maka ditanggung oleh pengelola dana.

Pihak bank harus lebih meningkatkan pengawasan terhadap para mitra aktif dengan cara membentuk tim monitoring pembiayaan dan mendatangi lokasi usaha mitra secara insidental agar dapat mempersempit celah penyimpangan dana oleh nasabah. Monitoring dilakukan untuk meminimalisir kecurangan data yang mungkin diterima oleh pihak bank.

Hal di atas berhubungan dengan upaya yang dilakukan muḍārib dalam menggunakan upayanya dalam proses humanisme. Dalam hal keadaan ekonomi yang tidak berubah, upaya yang dilakukan muḍhārib dalam menjalankan usahanya lebih mudah diukur, karena bank dalam hal ini melihat hasil dari usaha tersebut, kecuali terjadi krisis ekonomi atau hal lainnya yang mempengaruhi usaha nasabah tersebut, maka semaksimal apapun upaya yang dilakukan nasabah juga tidak menghasilkan profit yang besar.

Aktivitas keuangan dan perbankan dapat dipandang sebagai wahana bagi masyarakat modern untuk membawa mereka kepada pelaksanaan dua ajaran alQur'an.

Prinsip al Taawun, yaitu saling membantu dan saling bekerja sama diantara anggota masyarakat untuk kebaikan, sebagaimana dinyatakan dalam QS alBaqarah/2: 5. Terjemahnya :

"Pada hari Ini dihalalkan bagimu yang baik-baik. man (sembelihan) orangorang yang diberi Al Kitab itu halal bagimu, dan man kamu halal (pula) bagi mereka. (dan dihalalkan mangawini) wanita yang menjaga kehormatan diantara wanita-wanita yang beriman dan wanita-wanita yang menjaga kehormatan di antara orang-orang yang diberi Al Kitab sebelum kamu, bila kamu Telah membayar mas kawin mereka dengan maksud menikahinya, tidak dengan maksud berzina dan tidak (pula) menjadikannya gundik-gundik. barangsiapa yang kafir sesudah beriman (Tidak menerima hukum-hukum Islam) Maka hapuslah amalannya dan ia di hari kiamat termasuk orang-orang merugi" ${ }^{24}$

${ }^{24}$ Departemen Agama RI, al-Qur" anul Karim dan Terjemahnya, (Semarang: CV. Toha Putra, 2012), h. 3. 
Prinsip tolong menolong di dalam perbankan yaitu dengan bekerjasama bank secara bersama-sama dengan masyarakat dengan niat memunculkan kebaikanbagi masyarakat lainnya yang menggunakan jasa pembiayaan perbankan.

Perbankan harus merespon segala bentuk pelayanan tidak hanya dari nasabah, yang harus dilayani dan membutuhkan mereka pada saat itu. Tetapi seluruh calon nasabah adalah bagian dari pelyanan itu sendiri, kalaupun belum membutuhkan jasa pelayanan pada saat itu. Kebutuhan itu bisa di buat dengan adanya informasi ataupun sosialisasi. Komunikasi 2 arah ini sebagai pelayan dan yang dilayani ini menjadi bagian penting. Perbankan berusaha melayani nasabahnya dengan bertanya apa yang mereka butuhkan, memenuhi kebutuhan meraka, memberikan kebutuhan yang mungkin mereka belum sadar bahwa itu adalah kebutuhan dan hak yang harus diterima mereka. Inilah salah satu ciri humanistik dari pelayanan pembiayaan, bahwa manusia mempunyai fitrah yang sama dan seharunya sebagai manusia lainnya juga harus bisa saling memenuhi kebutuhan mereka.

BNI Syariah dalam mengetahui karakter calon nasabah/muḍhārib yang menerima pembiayaan, lebih kepada calon nasabah yang baru, untuk nasabah yang sudah pernah melakukan pembiayaan pada BNI Syariah, baik itu pembiayaan konsumif atau produktif, pihak bank lebih mudah memperoleh informasi mudhārib. Untuk nasabah yang sudah pernah melakukan pembiayaan sebelumnya, bank hanya perlu mengetahui tentang informasi yang belum ada sebelumnya, baik itu mengenai usaha yang dibiayai, prediksi mengenai kemampuan nasabah dalam menjalankan usaha dan jaminan yang dijaminkan jika terjadi wanprestasi.

BNI Syariah dalam menyeleksi calon nasabah untuk mendapatkan pembiayaan produktif dengan akad muḍhārabah cukup ketat. BNI Syariah bahkan menambah beberapa syarat atau kriteria tertentu yang masih mengedepankan sisi humanisme bagi calon nasabah pembiayaan dengan akad muḍhārabah. Untuk pembiayaan dengan akad muḍhārabah, pihak bank menetapkan kriteria yang lebih humanis, BNI Syariah juga memberikan pembiayaan dengan akad muḍhārabah kepada nasabah yang sebelumnya sudah pernah memperoleh pembiayaan dengan akad murabahah (jual-beli) atau musyarakah.

Dari penjelasan di atas dapat diartikan bahwa Bank BNI Syariah dalam menyalurkan pembiayaan dengan akad muḍhārabah walaupun berhati-hati tetapi tetap memperhatikan unsur humanisme. Tingginya risiko yang dihadapi bank syariah dalam pembiayaan dengan akad muḍhārabah menyebabkan bank lebih ketat dalam memilih nasabah pembiayaan dengan akad muḍhārabah. Walaupun hal ini berdampak pada rendahnya tingkat pembiayaan dengan akad muḍhārabah dibandingkan dengan akad musyarakah. 
Musyarakah merupakan akad kerja sama antara dua pihak atau lebih untuk suatu usaha tertentu diaman masing-masing pihak memberikan kontribusi dana (atau amal/prestise) dengan kesepakatan bahwa keuntungan dan resiko ditanggung bersama sesuai dengan kesepakatan. musyarakah mutanaqishah, akad kerja sama antara dua pihak atau lebih untuk suatu usaha tertentu dimana masing-masing pihak memberikan kontribusi dana dan secara bertahap salah satu pihak (bank) menurunkan jumlah partisipasinya.

Nasabah yang sebelumnya diberikan aqad pembiayaan sudah mau mundur karena beberapa alasan tetapi membatalkan niatnya. Persyaratan administrasi yang menjadi kendala bagi calon nasabah untuk memenuhi persyaratan tersebut adalah legalitas usahanya, jaminan yang diberikan dan nasabah tidak memperhatikan sistem administrasinya. Dan memang sebenarnya banyak calon nasabah yang mampu memenuhi persyaratan tersebut apabila pegawai bank mampu meyakinkan nasabah hal tersebut.

Status hukum dan lingkungan hunian yang tidak mantap. Misalnya ternyata ijin lokasi/persil perumahan belum memenuhi persyaratan bank teknis/aspek legalitas, sedang dalam sengketa atau sita jaminan dan sebagainya. Contoh: tanah yang sudah dikuasai oleh developer belum ditingkatkan statusnya menjadi HGB induk atas nama perusahaan atau sertipikat belum dipecah (splitzing) ata nama nasabah.

Calon nasabah tentu harus mengetahui terlebih dahulu bonafiditas dan kredibilitas pengembangannya. Tidak ada salahnya sedikit lebih rewel dengan mencari tahu informasi ke sana sini untuk memastikan keamanan dan kenyamanan tinggal di suatu tempat, baik dari aspek hukum (legalitas) maupun lingkungannya.

Untuk memberikan keyakinan kepada bank bahwa, sifat atau watak calon nasabah benar-benar dapat dipercaya. Keyakinan tercermin dari latar belg calon nasabah baik dari pekerjaan ataupun sosial masyarakat.

Hasil penelitian pada Bank BNI Syariah saat melakukan analisa pembiayaan mudarabah kepada calon nasabah, secara umum prinsip analisa pembiayaan di dasarkan pada analisa 5C. Analisa tersebut melalui analisa 5C yaitu $^{25}$ :

\section{Character}

Untuk memberikan keyakinan kepada bank bahwa, sifat atau watak calon nasabah benar-benar dapat dipercaya. Keyakinan tercermin dari latar belg calon nasabah baik dari pekerjaan ataupun sosial masyarakat.

${ }^{25}$ Kasmir, Manajemen Perbankan, ed.revisi, (Cet.VIII: Jakarta: PT.Rajawali Pers, 2008), h.65. 
Karakter menggambarkan watak atau kepribadian calon nasabah. Bank perlu melakukan analisis terhadap karakter calon nasabah dengan tujuan untuk mengetahui calon nasabah mempunyai keinginan untuk memenuhi kewajiban membayar kewajibannya sampai lunas. Keyakinan bank untuk mengetahui calon nasabah mau membayar kewajibannya sesuai dengan jangka waktunya. Ayat yang berkenaan dengan adab budi pekerti yang merupakan karakter pada Q.S.surah Al- hujurat/49:11-13 terjemahnya:

"Hai orang-orang yang beriman, janganlah sekumpulan orang laki-laki merendahkan kumpulan yang lain, boleh jadi yang ditertaw itu lebih baik dari mereka. dan jangan pula sekumpulan perempuan merendahkan kumpulan lainnya, boleh jadi yang direndahkan itu lebih baik. dan janganlah suka mencela dirimu sendiri dan jangan memanggil dengan gelaran yang mengandung ejekan. seburuk-buruk panggilan adalah (panggilan) yang buruk sesudah iman dan barangsiapa yang tidak bertobat, Maka mereka Itulah orang-orang yang zalim. Hai orang-orang yang beriman, jauhilah kebany purba-sangka (kecurigaan), Karena sebagian dari purba-sangka itu dosa. dan janganlah mencari-cari keburukan orang dan janganlah menggunakanjingkan satu sama lain. Adakah seorang diantara kamu yang suka mem daging saudaranya yang sudah mati? Maka tentulah kamu merasa jijik kepadanya. dan bertakwalah kepada Allah. Sesungguhnya Allah Maha Penerima Taubat lagi Maha Penyayang. Hai manusia, Sesungguhnya kami mencipt kamu dari seorang laki-laki dan seorang perempuan dan menjadikan kamu berbangsa - bangsa dan bersuku-suku supaya kamu saling kenal-mengenal. Sesungguhnya orang yang paling mulia diantara kamu disisi Allah ialah orang yang paling taqwa diantara kamu. Sesungguhnya Allah Maha mengetahui lagi Maha Mengenal".

Jangan mencela dirimu sendiri maksudnya mencela antara sesama mukmin karana orang-orang mukmin seperti satu tubuh. Panggilan yang buruk ialah gelar yang tidak disukai oleh orang yang digelari, seperti panggilan kepada orang yang sudah beriman, dengan panggilan seperti jelek dan sebagainya.

BNI Syariah mempunyai karakter humanisme dengan mengetahui bahwa calon nasabah mempunyai sifat jujur, karakter yang baik dan komitmen terhadap pelunasan kewajibannya melalui penelitian mendalam.

Pendekatan karakter (character approach). Pendekatan ini merupakan proses pemberian pembiayaan berdasarkan atas kepercayaan terhadap reputasi karakter bisnis dari calon nasabahnya. Pendekatan ini sangat tepat dilakukan oleh pihak bank apabila bank yang bersangkutan telah mengenal dengan baik reputasi karakter dari calon nasabahnya. Untuk mengetahui dan menilai karakter calon nasabah tersebut pihak BNI Syariah langsung terjun ke lapangan melalui petugas survey (account officer) untuk menlakukan pengecekan ke calon nasabah dan lingkungan dimana calon nasabah itu tinggal dan di lingkungan nasabah itu 
bekerja apakah calon nasabah tersebut mempunyai masalah atau tidak, setelah itu petugas survey mendatangi rumah calon nasabah untuk mengetahui kondisi rumah calon nasabah sekaligus mewawancarai calon nasabah tersebut apakah pernyataan calon nasabah tersebut sesuai dengan info yang didapat dari lingkungan di sekitar calon nasabah tinggal dan juga dari lingkungan tempat kerjanya.

Dasar dari pemberian pembiayaan adalah kepercayaan, jadi yang mendasari suatu kepercayaan yaitu adanya keyakinan dari pihak bank bahwa si peminjam memilki moral, watak, ataupun sifat- sifat pribadi yang positif dan kooperatif dan juga mempunyai rasa tanggung jawab baik dalam kehidupan pribadi sebagai manusia, masyarakat, atau dalam menjalankan kegiatan usahanya. Manfaat dari penilaian character ini, adalah untuk mengetahui sejauh mana tingkat kejujuran dan integritas serta tekad yaitu kemauan untuk memenuhi kewajiban-kewajiban dari calon nasabah, character ini sangat penting, sebab walaupun nasabah tersebut mampu membayar hutang-hutangnya namun tidak ada etiket baik tentu membawa berbagai masalah bagi bank di kemudian hari. Sebelum terjun ke lapangan biasanya petugas survey melihat SID (Sistem Informasi Nasabah) calon nasabah, apakah calon nasabah masih mempunyai tanggungan di bank lain dan tanggungan/ pinjaman tersebut bermasalah. Dari SID tersebut juga dapat menilai character yang dimiliki oleh calon nasabah karena pihak bank dapat mengetahui dan melihat bagaimana calon nasabah dalam memenuhi kewajiban-kewajibannya Setelah semua Aministrasi lengkap, maka sijalankan semua prosedur pencairan pembiayaan.

Dalam menilai character seseorang bukanlah hal yang mudah, karena kita memerlukan ketrampilan psikologis untuk dapat menilai karakter seseorang. Adapun cara menilai character calon nasabah dengan cara:

1) Meneliti daftar riwayat hidup nasabah dengan cara wawancara langsung dengan nasabah ataupun bertanya kepada masyarakat di lingkungan calon nasabah tinggal.

2) Meneliti reputasi calon nasabah di lingkungan tempat kerja.

3) Meneliti apakah calon nasabah terlibat pada suatu masalah, penjudian, perampokan, pemabuk dan lain-lain.

4) Meminta informasi dari bank lain, di sini yang dimaksud mengecek SID (Sistem Informasi Nasabah) calon nasabah, apakah masih mempunyai tanggung pada bank atau pihak lain.

\section{Capacity}

Untuk melihat kemampuan nasabah dalam membayar pembiayaan atau pembiayaan yang dihubungkan dengan kemampuan mengelola bisnis dan mencari laba. Perhitungan besarnya pendapatan bersih dari calon nasabah yang sudah dikurangi pengeluaran bulanan. Bank mempertimbangkan besarnya angsuran 
yang dibebankan kepada calon nasabah tidak lebih dari $40 \%$ penghasilan bersih yang diterima oleh calon nasabah.

Yang dimaksud capacity di sini kemampuan nasabah dalam melunasi kewajiban-kewajibannya dari kegiatan usaha yang dilakukan atau yang dilakukan yang dibiayai oleh bank. Penghasilan bersih nasabah yang diterima adalah maksimal angsuran nasabah terhadap pembiayaannya. Q.S.Almaidah/5:92, terjemahnya:

"Dan taatlah kamu kepada Allah dan taatlah kamu kepada Rasul-(Nya) dan berhati-hatilah. jika kamu berpaling, Maka Ketahuilah bahwa Sesungguhnya kewajiban Rasul kami, hanyalah menyampaikan (amanat Allah) dengan terang"

Sampai sejauh mana usaha yang diperolehnya, mampu melunasi tepat waktu sesuai perjanjian yang telah disepakati. Pengukuran capacity ini, dapat dilakukan dengan berbagai pendekatan, yaitu :

1) Pendekatan historis, yaitu menilai past performance dari nasabah yang bersangkutan apakah usahanya banyak mengalami kegagalan atau selalu menunjukkan ke arah yang maju

2) Pendekatan finansiil, yaitu dengan menilai posisi neraca dan laporan perhitungan rugi/laba untuk beberapa periode terakhir, yaitu untuk mengetahui berapa besarnya solvabilitas, likuiditas, dan rentabilitas tingkat usahanya.

3) Pendekatan edukasional, yaitu menilai latar belg pendidikan para pengurus perusahaan calon beditur.

4) Pendekatan yuridis, yaitu menilai apakah calon nasabah tersebut secara yuridis mempunyai kapasitas untuk mewakili dirinya atau badan usaha yang diwakilinya untuk mengad ikatan perjanjian pembiayaan dengan bank.

5) Pendekatan managerial, yaitu untuk menilai sejauh mana kemampuan nasabah dalam melaksan fungsi menagemen dalam memimpin perusahaannya.

6) Pendekatan teknis, yaitu menilai sejauh mana kemampuan calon nasabah dalam mengelola faktor - faktor produksi seperti tenaga kerja, bahan baku, peralatan - peralatan kerja/ mesin, administrasi dan keuangan bahkan sampai pada kemampuan merebut pangsa pasar.

Apabila dana yang dicairkan untuk pembiayaan barang konsumsi, maka penilaian capacity nasabah didasarkan pada pekerjaan yang sedang dikerj oleh nasabah saat ini dan seterusnya. Dari situ pihak bank dapat menyimpulkan apakah nasabah tersebut mampu melunasi kewajiban-kewajibannya.

BNI Syariah melihat kemampuan calon nasabah dalam membayar pembiayaan dihubungkan dengan kemampuannya mengelola bisnis serta 
kemampuannya mencari laba. Sehingga pada akhirnya terlihat kemampuannya dalam mengembalikan pembiayaan yang disalurkan

Penilaian capacity nasabah didasarkan pada pekerjaan yang sedang dikerj oleh nasabah saat ini dan seterusnya.

\section{Capital}

Untuk mengetahui sumber-sumber pembiayaan yang dimiliki nasabah terhadap usaha yang dibiayai oleh Bank. Q.S. Al-Baqarah/2:279, terjemahnya:

"Maka jika kamu tidak mengerjakan (meninggalkan sisa riba), Maka Ketahuilah, bahwa Allah dan rasul-Nya memerangimu. dan jika kamu bertaubat (dari pengambilan riba), Maka bagimu pokok hartamu; kamu tidak menganiaya dan tidak (pula) dianiaya".

Modal dari nasabah digunakan untuk mengetahui sumber-sumber penghasilan yang dimiliki nasabah terhadap usaha yang dibiayai oleh bank. Bank Syariah tidak semua bersedia untuk membiayai seluruh kebutuhan pembiayaan suatu usaha, artinya setiap nasabah yang mengajukan permohonan pembiayaan harus pula menyediakan dana dari sumber lainnya atau modal sendiri. Setiap nasabah harus mempunyai capital saat mengajukan pembiayaan, uang muka pembiayaan harus disiapkan oleh nasabah pembiayaan. Hal tersebut menand kekuatan sumber nasabah saat mengajukan pembiayaan.

BNI Syariah menilai dari jumlah dana atau modal sendiri yang dimiliki oleh calon nasabah. Sebagai contoh apabila calon nasabah meminta pihak bank untuk membiayai pembelian sepeda motor, maka pihak bank harus mengetahui berapa besarnya persentase uang muka yang diberikan oleh calon nasabah. Bank berani membiayai pembelian sepeda motor apabila besarnya uang muka dari harga beli sepeda motor tersebut. Sedangkan untuk pembiayaan dengan jaminan surat kepemilikan kendaraan bermotor, pihak bank bisa mencairkan dana dari harga taksasi sepeda motor tersebut.

\section{Collateral}

Merupakan jaminan yang diberikan calon nasabah kepada bank. Nilai jaminan hendaknya melebihi jumlah pembiayaan yang diberikan. Sehingga jika terjadi suatu masalah jaminan yang diberikan dapat digunakan untuk memenuhi kewajiban nasabah. Bank menilai pembiayaan layak diberikan atau tidak dilihat dari jaminan atau prinsip collateral yang diberikan oleh nasabah kepada bank. Bank dapat mencairkan pembiayaan apabila nilai dari jaminan tersebut sebanding dengan pembiayaan yang diajukan. Hal ini dibutuhkan sebagai pengaman apabila pembiayaan yang telah diberikan gagal atau nasabah tidak dapat melunasi kewajiban-kewajibannya.

Merupakanakan jaminan yang diberikan calon nasabah baik jaminan yang bersifat fisik pembiayaannya langsung ataupun jaminan yang bersifat fisik 
pembiayaan tidak langsung. Jaminan hendaknya melebihi jumlah pembiayaan yang diberikan. Fungsi jaminan tersebut adalah sebagai jaminan bank dari resiko kerugian. Q.S. Al-Baqarah/2:283, terjemahnya :

"Jika kamu dalam perjalanan (dan bermu'amalah tidak secara tunai) sedang kamu tidak memperoleh seorang penulis, Maka hendaklah ada barang tanggungan yang dipegang[180] (oleh yang berpiutang). tetapi jika sebagian kamu mempercayakanai sebagian yang lain, Maka hendaklah yang dipercayai itu menunaikan amanatnya (hutangnya) dan hendaklah ia bertakwa kepada Allah Tuhannya; dan janganlah kamu (para saksi) menyembunyikan persaksian. dan barangsiapa yang menyembunyikannya, Maka Sesungguhnya ia adalah orang yang berdosa hatinya; dan Allah Maha mengetahui apa yang kamu kerj. Barang tanggungan (borg) itu diad bila satu sama lain tidak percaya mempercayakanai".

Pendekatan jaminan (collateral approach). Pendekatan ini dilakukan sebagai dasar dalam menganalisa pembiayaan yaitu pembiayaan diberikan apabila calon nasabah mempunyai jaminan memadai baik ditinjau dari nilai ekonomi ataupun dari uang (pembiayaan) yang dilepaskan oleh pihak bank kepada calon nasabahnya atau calon nasabahnya. Pembiayaan modal kerja yang menggunakan jaminan sertifikat tanah dan bangunan, pihak bank harus mengetahui harga pasaran ataupun nilai dari jaminan tersebut dan kemudian harga pasaran tersebut ditaksasi. Setelah diperoleh harga taksasi tersebut bank baru dapat memberi keputusan besarnya pembiayaan yang dapat dicairkan.

Barang-barang jaminan yang diberikan oleh peminjam sebagai jaminan atas pembiayaan yang diterima. Manfaat collateral adalah sebagai alat pengamanan apabila usaha yang dibiayai dengan pembiayaan tersebut gagal atau sebab lain di mana nasabah tidak mampu melunasi hutangnya. Jaminan juga sebagai alat pengaman dalam menghadapi kemungkinan adanya ketidakpastian pada kurun waktu yang datang pada saatnya pembiayaan tersebut harus dilunasi. Jaminan ini sifatnya sebagai pelengkap dari kelay/keterlaksanaan dari proyek nasabah. Penilaian terhadap collateral ini harus ditinjau dari 2 sudut yaitu sudut ekonomisnya yaitu nilai ekonomis dari barang-barang yang dijaminkan, serta nilai yuridisnya yaitu apakah barang-barang jaminan tersebut memenuhi syaratsyarat yuridis untuk dipakai sebagai barang jaminan.

\section{Condition}

Yang dimaksud dengan condition of economy yaitu situasi dan kondisi politik, sosial, ekonomi, budaya dan lain-lain yang mempengaruhi keadaan 
perekonomian pada suatu saat maupun untuk suatu kurun waktu tertentu yang kemungkinannya dapat mempengaruhi kelancaran usaha dari perusahaan yang memperoleh pembiayaan.

Condition of economy sangat penting untuk diketahui apabila pembiayaan tersebut diberikan untuk perusahaan-perusahaan yang bergerak di luar negeri sendiri. Faktor-faktor makro ekonomis ini termasuk pula peraturanperaturan pemerintah setempat sangat berpengaruh terhadap suksesnya suatu perusahaan. Condition of economy digunakan sebagai pendukung untuk menguatkan data calon nasabah. Apabila salah satu dari prinsip capital atau prinsip condition of economic tidak mendukung tetapi calon nasabah mempunyai character yang baik, mempunyai collateral (jaminan) yang nilainya sesuai dengan besar pembiayaan yang diajukan dan mempunyai capacity yang baik, maka pihak PT. BPR Nguter Surakarta masih dapat mempertimbangkan untuk dapat membantu dalam pembiayaan ataupun pencairan pembiayaan yang diajukan oleh calon nasabah.

Penilaian terhadap condition of economy dimaksudkan pula untuk mengetahui sampai sejauh mana kondisi-kondisi yang mempengaruhi perekonomian suatu negara/ suatu daerah memberikan dampak yang bersifat positif maupun dampak yang bersifat negatif terhadap perusahaan yang memperoleh pembiayaan tersebut.

\section{PENUTUP}

\section{A. Kesimpulan}

Berdasarkan penelitian yang dilakukan oleh penulis, Penelitian ini bertujuan untuk menjawab dua rumusan masalah dan dari hasil pembahasan dapat disimpulkan sebagai berikut:

1. Optimalisasi Pembiayaan Mudarabah.

Yang pertama terkait optimalisasi pembiayaan Mudhārabah pada Bank BNI Syariah, dilakukan dengan: BNI Syariah telah melakukan beberapa tindakan optimalisasi pembiayaan mudarabah.

BNI Syariah dalam optimalisasi pembiayaan Muḍārabah tidak terlihat bahwa ada unsur kesengajaan meminimalkan pembiayaan Mudhārabah dibandingkan pembiayaan musyarakah dan murabahah, walaupun setiap tahun mengalami peningkatan tetapi tetap pembiayaan musyarakah dan murabahah lebih tinggi dibandingkan pembiayaan Mudhārabah.

Terkait mengoptimalkan pembiayaan Mudhārabah pada BNI Syariah Makassar yaitu dengan melakukan beberapa inovasi optimalisasi diantaranya pemenuhan Kuantitas dan peningkatan kualitas SDI, maka BNI Syariah selaku şhāhibul māal perlu membuat terobosan yang memenuhi harapan kedua belah pihak. Karena hal ini berdampak pada pengungkapan karakter nasabah yang jujur, level upaya yang dilakukan muḍhärib lebih maksimal dan meningkatnya 
profit yang dihasilkan muḍhārib secara otomatis pihak bank juga mendapatkan bagi hasil yang besar dari profit yang dihasilkan.

2. Pembiayaan berbasis Humanisme

Dalam pembiayaan berbasis humanisme pada BNI Syariah menerapkan $5 \mathrm{C}$ terhadap pengambilan keputusan Pembiayaan Mudarabah, BNI Syariah lebih menekankan prinsip Character, Collateral, dan Capital, sedangkan prinsip lainnya yaitu Capital, dan Condition of economy digunakan sebagai pendukung untuk menguatkan data calon nasabah. Prinsip character lebih diutam oleh bank dalam mengambil keputusan pembiayaan, karena prinsip ini berperan penting dalam menilai calon nasabah. Dengan prinsip ini pihak bank dapat mengetahui kesungguhan dari calon nasabah yang ingin mengajukan pembiayaan. Selain itu prinsip karakter merupakan salah satu prinsip yang mutlak dan tidak dapat ditawar-tawar. Apabila salah satu dari prinsip capital atau prinsip condition of economic tidak mendukung tetapi calon nasabah mempunyai character yang baik, mempunyai collateral (jaminan) yang nilainya sesuai dengan besar pembiayaan yang diajukan dan mempunyai capacity yang baik, maka pihak masih dapat mempertimbangkan untuk dapat membantu dalam pembiayaan yang diajukan.

Penerapan atau aplikasi teori humanistik tercermin dari perilaku pegawai terhadap nasabah pembiayaan, dimana pegawai berperan sebagai pelaku utama yang memaknai proses pembiayaan kepada nasabah.

Proses pembiayaan mudarabah memberikan pembelajaran yang mengedepankan bagaimana memanusi nasabah dengan perilaku humanisme.

Salah satu prinsip humanisme berkarakter, bahwa manusia itu mempunyai kemampuan secara alami, artinya setiap manusia memiliki rasa melayani dan bertanggung jawab yang mendalam pada dirinya.

Adanya keterbatasan yang ada dilakukan untuk perbaikan pada masa mendatang, diantaranya sebagai bahan pertimbangan untuk mengembangkan dan memajukan perusahaan.

a) Optimalisasi yang diterapkan sudah maksimal dalam memgembangkan pembiayaan mudarabah dan mendapatkan peningkatan kualitas dalam pembiayaan khususnya pembiayaan mudarabah.

b) Adapun resiko di BNI Syariah bisa memenuhi tingkat keamanan bagi bank, sehingga harus diminimalisir resiko-resiko pembiayaan. Maka dari itu diharapkan BNI Syariah mampu terus menjaga dan menerapkan optimalisasi tersebut.

c) Humanisme yang dimiliki BNI Syariah mempunyai kelebihan yaitu dari sisi humanisme dalam pembiayaan mudarabah, sehingga dalam proses pembiayaan memberikan kenyamanan dari unsur pegawainya kepada setiap nasabah pembiayaan mudarabah.

d) BNI Syariah yang mampu membuat kebijakan pembiayaan Mudarabah yang berbasis humanisme dalam membentuk karakter nasabah bertanggung jawab, diantaranya menyelesaikan kewajiban dan mampu menyelesai masalah yang dihadapi. 


\section{DAFTAR PUSTAKA}

Abdul Ghofur Anshori,2007, Perbankan Syariah di Indonesia,Yogyakarta: Gajah Mada University Press,.

Abdullah ZakyAl-Kaaf, 2002, Ekonomi dalam Perspektif Islam, Bandung: CV Pustaka Setia,.

Achmadi Usman, Aspek-Aspek Hukum Perbankan di Indonesia. Jakarta: Gramedia Pustaka, Utama, 2005.

Adi Nugroho. 2005. Faktor-faktor Yang Mempengaruhi Margin Pembiayaan Murabahah (Studi kasus pada PT.Bank Muamalat Indonesia). Universitas Indonesia.

Adiwarman A. Karim. 2006. Bank Islam; Analisis Fiqih dan Keuangan. Edisi tiga. Jakarta : PT Raja Grafindo Persada.

Karim, Adiwarman A, 2004. Bank Islam analisis Fiqh dan Keuangan. Jakarta: PT Rajagrafindo Persada.

Muhammad Syafi'i Antonio, 2001. Bank Syariah Dari Teori Ke Praktek, Jakarta: Gema Insani Press,. , 2002. Manajemen Bank Syariah. Yogyakarta: (UPP) AMPYKPN. 